\title{
Camplessness and the (non-)reception system: the emerging of migrant informality in northern Italy from a human rights perspective
}

\author{
No-campos y el sistema de no-recepción: el surgimiento \\ de informalidad migratoria en el norte de Italia desde una \\ perspectiva de derechos humanos
}

Sebastian Benedikt

University of Göttingen

s.benedikt@posteo.de

Citation/Cómo citar: Benedikt, Sebastian. 2020. "Camplessness and the (non-)reception system: the emerging of migrant informality in northern Italy from a human rights perspective». Deusto Journal of Human Rights, n. 5: 243-268. doi: http://dx.doi.org/10.18543/djhr.1795

\begin{abstract}
Summary: Introduction. 1. Northern Italy: borderland in the shadow of the Mediterranean. 2. Informality as a housing condition for migrants. 2.1. Migrant informality as a research field. 3. Informality in Italy. 3.1. Classifying and quantifying migrants in informality in Italy. 4. Methodology and sample. 4.1. Some limitations. 5. Results: Reasons for the emerging of informality and living realities outside the boundaries of reception. 5.1. Informality and mobility: an interdependence. 5.2. Informality and the overstrained reception system. 5.3. Living realities and issues in informality. 6. Camplessness and human rights. 6.1. (Im-)mobility as an effect of EU law. 6.2. On the wrong side of the law: the (non-)reception system. 6.3. Outside the boundaries of reception and outside the boundaries of law. 6.4. Future perspective and role of the findings for the research field. Conclusion. References.
\end{abstract}

Abstract: Despite the decrease of arrivals, the routes of migration to Europe are still open and hundreds arrive every month. Italy is overstrained with the migratory influx and informal settlements are emerging as alternative shelters. While boat crossings attract attention, silence prevails over what happens in northern Italy. This article sheds light into informality in northern Italian regions and analyses the living realities from a human rights perspective. For that, an ethnographic research was conducted on the Austrian and French 
borders. Migrants drop and step-out of the reception system due to the congestion and the deplorable living conditions. They are exposed to violence, criminality, repression and natural hazards; they are highly mobile and suffering increasing marginalization and vulnerability. The institutional answer consists in forced evictions and transfers, leading into a vicious circle of informality. The living realities migrants encounter in Italy are not in line with fundamental human rights and contradict international law. rights

Keywords: migrants, refugees, informality, migrant mobility, Italy, migrants'

Resumen: A pesar de la disminución de las llegadas, las rutas migratorias hacia Europa siguen abiertas y cientos de personas llegan cada mes. Italia está sobrecargada por los flujos migratorios y surgen asentamientos informales como refugios alternativos. Mientras las llegadas por mar centran la atención, el silencio es sepulcral sobre lo que sucede en el norte de Italia. Este artículo arroja luz sobre la informalidad migratoria en las regiones septentrionales desde la perspectiva de los derechos humanos. Para ello, se ha realizado una investigación etnográfica en las fronteras con Austria y Francia. Los migrantes abandonan y salen del sistema de acogida debido a la congestión y a las deplorables condiciones de vida. Están expuestos a la violencia, la delincuencia, la represión y los riesgos naturales. Los migrantes presentan un alto nivel de movilidad y sufren una creciente marginación y vulnerabilidad. La respuesta institucional son desalojos y traslados forzosos, lo que conduce a un círculo vicioso de informalidad. La situación de los migrantes en Italia no respeta los derechos humanos y deja de lado el derecho internacional.

Palabras clave: migrantes, refugiados, informalidad, movilidad migratoria, Italia, derechos del migrante 


\section{Introduction}

After the "long summer of migration", as it was named by Hess et al. (2017), ended with the closure of the Balkan Route in 2016, the Central-Mediterranean Route from Libya to Italy became again the main axis for migrants to Europe. In 2017, Italy received $65 \%$ of the asylum seekers and refugees who reached Europe by sea (UNHCR 2018). Even though the number of sea and overt arrivals decreased in 2017, the number of asylum applications, and with it the amount of people entitled to accommodation in a second-grade reception facility in Italy, rose. In the last two years, the number of sea-arrivals dropped, in 2019 only 10,000 migrants disembarked on Italian shores (UNHCR 2019). Figures are misleading though; the total amount of arrivals is much higher, as the proportion of covert migrants is increasing (Cosgrave et al. 2016, 10). The meticulous records exclude the different kinds of land-arrivals, autonomous arrivals and migrants entering Italy fuori quota. ${ }^{1}$ Land arrivals can be either migrants coming via the Balkan Route or migrants returning from other EU countries.

For the returns there are mainly two scenarios. The first is pushbacks; the second is returns and deportations back to Italy due to the reimplementation of the Dublin proceedings. In 2018, 31,000 migrants entered Italy pursuant to a Dublin procedure and only around 23,400 by sea (Camera Deputati 2018). The Italian reception system is still unable to absorb these numbers, so it is under constant strain and was not significantly enlarged over the years. Consequently, informal shelter options arose and as the Italian state has not foreseen a secondgrade reception solution for returnees, it must be assumed that the "Dubliners" enter informality (AIDA 2018, 15; MSF 2016, 12).

So, as there are ten thousands of migrants in Italy and as the focus of academia and media still lies on the sea-landings, it is worth to recall Pinelli $(2015,12)$ and ask again: "what happens after the landing?"

Landing is followed by phases of uncertainty, taking place in refugee and migrant camps, which are zones of indistinction between norm and exception and between fact and law. The inhabitants are neither integrated in the judicial system nor enjoying legal protection, they are deprived of their political existence and legal personality and exposed to "bare-life" as Agamben $(1998,181)$ once put it. Camps are

1 Fuori quota are refugees or immigrants who do not arrive by boat, but in an "unofficial" or "independent" way. The migrants coming back from other EU states are all fuori quota (ASGI, Antenne Migranti, and Fondazione Alexander Langer Stiftung $2017,8)$. 
places of permanent exception, where the "temporary suspension of the rule of law is given a permanent spatial arrangement" (Agamben $1998,169)$. If this applies to refugee camps in their official sense, what is then the situation in informal settlements, in non-permanent spatial arrangements of refuge?

Even though there are various scholars who argued against approaching migrants and their camps through the lens of pure exception and bare life (inter alia: Sigona 2015; Turner 2016), I want to integrate Agamben's approach, since for the interpretation and critical salience of a social phenomenon it is still an indispensable concept (De Genova 2012, 132). I agree that it is worth to "de-exceptionalise" the camp and its residents, but, and as this article will display, informality and the factual non-existence of camps, the "camplessness", cannot fall under the de-exception of camps; because informal settlements are "non-camps", now emerging as the exception of the (de-)exception. The retake of bareness is helpful in order to analyse the non-existence of camp spaces, but it does not mean that aspirations of migrant autonomy and individualism are left aside, in fact they go hand in hand.

In order to present my findings, at first, I will give a short overview about northern Italy; secondly about migrant informality; and interlink them in the third part. These more theoretical backgrounds are complemented by a brief notice about the methodology I used in the fourth section. The fifth part then presents and explains the results, which will be discussed and assessed from a human rights perspective in the sixth part, leading into the concluding remarks.

\section{Northern Italy: borderland in the shadow of the Mediterranean}

As sea-arrivals are in the focus of immigration records in Italy, so are the regions where these take place. Academic reports emphasize the southern regions and the Mediterranean but overlook the rest of the country. The North as a borderland is gaining more importance though, because Austria, Switzerland and France are not only countries where migrants aim at, they are now as well countries where migrants come back from. The North is a crucial point for refugees and migrants; it is not only a region of transit further into the EU, it became an entry point for returnees and autonomously moving migrants as well. I call the border regions of the North the "two-sided-bottleneck" of migratory movements in Italy. An area of transit into and out of the country, an area of mobility and immobility and of informal housing. 
There are four focal points for transit migration in northern Italy; Ventimiglia on the frontier with France, Como on the border with Switzerland, Brenner Pass on the Austrian border and Gorizia, next to Slovenia. Together with Ventimiglia and Como, Brenner Pass is one of the most important spots to leave Italy. I concentrate my analysis on two sites; firstly, on the so-called Brenner Route, the migration channel through the Central-North along Trento, Bolzano and Brennero. Secondly, on Ventimiglia, the border village called the "Calais of Italy" (Giuffrida 2018), where hundreds of migrants gather and try to cross to France.

These sites were chosen for the investigation, because both were also estimated to be areas of returns and pushbacks, of covert migration and of growing informality, as the migrants coming down from northern Europe are all fuori quota and hence very likely to inhabit informal sites. The aim was to gain an inside view into these spaces of seclusion and to show how the Italian reception system together with the European border regime affect migrants' lives and their fundamental rights. This article shall contribute to a critical discussion about the European answer to recent immigrations and shows how human rights, enshrined in a vast set of legal instruments, fall short to protect the ones seeking refuge even inside the EU.

\section{Informality as a housing condition for migrants}

The "campization", the diffusion of camps all over Europe was displayed as an occurrence of the migrant arrivals since 2015 (Kreichauf 2018). An inherent part of this phenomenon is the expansion of informal encampments, of migrant settlings outside of the reception system. Their emergence is not so recent though, considering that the Calais "Jungle" accrued already in the 1980s (Dembour and Martin 2011, 126).

In order to grasp the phenomenon of migrant informality in Italy, firstly it remains to outline what informality is. Naturally the concept is quite vast, and the five types of informal settlements proposed by UNECE only indicate the multidimensionality of informality. Alternative shelter solutions of migrants in Italy can be subsumed under the second type, "settlements for refugees and vulnerable people" (UNECE $2009,8)$. Informal refugee settlements are:

"established in an unplanned and unmanaged manner, [...] are generally unrecognized [...] [and] formally defined as [...] unofficial groups of temporary residential structures, often comprising of 
plastic sheeting and timber structures [that] can be of any size from one to several hundred tents" (UNHCR Lebanon 2016).

According to Agier $(2002,337)$ informal settlements are to be found in peripheral areas (either rural or urban) that are illegally occupied and of temporary character. They can be constituted of tents, collective shelters, (unfinished) constructions, garages, squats and separate rooms (Habib et al. 2016, 1043).

It is a delicate task to find a more precise specification in academia, scholars rather outline informality, than dare to define it. As informal camps vary widely from one to another, it is a major issue to analyse the concept as one, due to its social and spatial unevenness.

In order to grasp informality, Brighenti's (2016) notion of "interstice", of being "in-between" is worth invoking; informal camping is not only a legal interstice as described by Fontanari and Ambrosini $(2018,594)$, but a temporal interstice, a housing solution between different stages in the asylum process or in transit. Thus, informality is implicitly also a spatial interstice, namely the shelter option between different reception facilities or stages on the flight. For Queirolo $(2017,225)$ informal settlings are an integral part of the limbo migrants are caught in; of finding a camp, of being forced to leave it, of asylum opportunities and of escaping surveillance.

When approaching informality from camp scholarship, it becomes clear, that informal settlements are not camps. It seems easier to draw the line between what is defined as a camp and what is not, than to find a universal explanation for informality. Taking Turner's (2016, 139) treatise about what refugee camps are as a reference, one cannot find the apt analogy for informality, because informality cannot be defined according to Turner's dimensions of temporality and spatiality. Migrants in informality are further not integrated in the "fine-grained modes of government", nor enjoying protection or any regime of care, what Turner $(2016,144)$ takes as inherent parts of refugee camps. Informal camps lack official recognition and are not seen as spaces of humanitarian emergency. The need for aid is not identified by state actors, which precludes the population from protection (Sanyal 2017, $118,123)$. Being outside camp attributes, makes migrants in informality what I deem "campless" and informal settlings "non-camps", as their characteristics of unhealthy living, substandard housing in inadequate structures, precariousness, insecurity and exposure are not of the camp defining terms. Informal settlements challenge our ideas of camps and governance and we need to develop a concept to think beyond camps, in order to precisely define informal non-camps. 
Contrary to official camps, informal settlements are products of migrants' needs and imagination, built to facilitate their lives and their ability to move. De Genova et al. $(2018,249)$ suggested to reconsider the politics of asylum and the struggles for asylum from the autonomy of migration gaze. I adhere informal settlings as spatial objectifications of migrant autonomy. Tazzioli and Garelli $(2019,406)$ describe informal encampments as "temporary spaces of transit and refuge", which are a consequence of the conflict of migratory movements and state strategies to control and restrict them. Their transient character, and their position as an antithesis to regular camps make them "counter-camps" (Minca 2015, 90). I thus propose to regard informal settlements as the realisation of individual aspirations, as a form of migrant resistance for mobility, freedom and human rights. They are not only legal, temporal and spatial interstices, but as well interstices of autonomy.

\subsection{Migrant informality as a research field}

Analysing informality slowly gained importance as a by-product of refugee camp research. Informal migrant housing, its implications and effects have been studied intensively during the last decades in Lebanon. The academic interest was so high that refugees in Lebanon were even declared an "over-researched" population (Sukarieh and Tannock 2013, 494). Informality as a consequence of the recent migration influx has barely been studied though and in northern Italy informal encampments are rather "under-researched", especially compared to other regions in and around Europe.

Undoubtedly, there is the need to investigate the living realities of migrants in Europe and especially about migrants in precariousness, in order to monitor, understand and follow the repercussions of the long summer of migration. It remains to find answers to Sanyal's $(2017,118)$ question about the "future of refuge" from a European perspective and to shed light on the "grey spaces" informal settlings inhabit.

So far, informality research is concentrated on Greece and particularly the French Calais, being the epitome of informal migrant camps in the EU. When it comes to Italy, scholarship focused on the informal camps in the South (Corrado 2011; Cristaldini 2015; Piro and Sanò 2017; Sanò 2017; Brekke and Brochmann 2015) or in Rome (Korac 2003; Puggioni 2005; Belloni 2016). In both areas however, informal settling is not directly linked to the long summer of migration or 
its aftermath. In the North, research has been conducted mostly in Ventimiglia, the attention however was usually drawn on mobility rather than informality (Fontanari 2017; 2016; Tazzioli and Garelli 2018; 2016; Picozza 2017; Aris 2018; Menghi 2018). Thus, there is a knowledge discrepancy between the North and the rest of Italy and between newly (post 2015) emerging settings of informality and more established ones.

Most information hereto is given by Busetta et al. (2019), but primarily by NGOs (Caritas and Ministero dell'Interno 2012; MSF 2016; 2018a; 2018b). It must be remarked, that these often exclude the Brenner Route, and/or smaller informal settlings, and/or are not of an academic origin. In addition, they emphasize the living conditions and in particular health issues but not the causes for the emerging of informal settlings or the links between these, the living conditions and human rights.

However, these studies build a base for informality research in Italy and demonstrate the novelty of the field. This article aims to join the approaches of filling the gap of knowledge and to provide further academic analysis of migrant informality in high-income/European countries and of the contradicting realities regarding the human rights regimes of such states.

\section{Informality in Italy}

It must be remarked that informal migrant housing is not a recent tendency in Italy, as decades of informal migrant worker camps in the South prove. Immigration through the Mediterranean has been a common way to enter Europe ever since and autonomous migrant settling has always been a side-effect. During the last decades, the regions of Calabria, Puglia and Sicily with their strong agriculture and proximity to the sea, were the main areas of informal settling. Today, mostly African immigrants work in the southern agriculture, fully exploited and dependent. They inhabit tent villages (tendopoli), informal encampments in ghettoised structures, like the gran ghetto in San Severo (Cristaldini 2015, 122, 127; Borri and Fontanari 2015). Albeit there are regions with a higher prevalence of makeshift camps, they are a countrywide phenomenon. Hess $(2012,435)$ clarifies: informality arises close to precarious transit zones, which are not only a result of the border regime, but as well of the migrants' objectives to make use of informal working opportunities, networks or transport technologies. 
Informal encampments can be categorized in two different types. The first type consists in migrant worker camps, composed of buildings, fabric halls, containers, sheds or tents. These often exist for decades, offering shelter for migrants coming from different regions and backgrounds who never entered the reception and asylum system or who left it on their own account. The second type is rather recent and can be found all over the country, firstly recognized at around 2011. It emerged around cities and strategic transitory places, where errant subjects, a population of homeless or as I put it, campless migrants, searched recovery and tried to reorient their migration objectives (Fontanari 2017, 40). These places are less elaborated than the ones of the first type and often open-air. Their dwellers are refugees and migrants who are waiting to access the reception system and who are highly mobile in terms of time and space (AIDA 2018, 14; MSF 2016, 8).

With the increasing number of migrants, the amount of those living in informal encampments, especially of the second type, grew steadily. The Italian reception system was and is not able to tackle informality effectively. Despite several initiatives of harmonization and various modifications in the last years, the reception system as such is still rather complex (Giannetto et al. 2019). The system is in essence composed of first- (CPSA, CDA/CARA) and second-grade (SPRAR/ SIPROIMI, CAS) reception facilities, whereas the scarcity of places in the latter is one of the main reasons for the emerging of informal housing (see infra). Another important factor is the limited time migrants are entitled to remain in first-grade facilities, which differ between a few and 35 days (AIDA 2018). In addition, the conditions in the hotspots, the reception centres and the emergency camps are devastating. In some cases, they could not even reach the minimum standards of dignified living (Sperber 2018, 1469). The needs could not and still cannot be met and even migrants who are formulating an asylum appeal face an impeded and delayed access to the mostly unsatisfactory reception system (MSF 2016, 4; Giannetto et al. 2019, 36).

The adoption of the Salvini Decree (Decree-law no. 113 of 4 October, converted into Law no. 132 of 1 December 2018) further aggravated the situation. The decree imposed legislative changes on immigration, legal statuses and the reception system. The law repealed the status of humanitarian protection in Italy and excluded around 130.000 migrants (until 2020) from the reception system and the protection mechanisms at once, pushing them into informality. This revocation converted them from legal to "illegal" migrants and produced a "growing overlap between illegalized migrants and asylum 
seekers" in the public perception (Campesi and Fabini 2020; Tondo and Giuffrida 2018). The decree and its massive expulsion of migrants with a legal claim for protection out of the reception system marked not only a radical change in the Italian immigration strategy, it can be as well understood as a prime example for institutional racism (Khrebtan-Hörhager 2019).

In the northern province of Alto Adige, the diffusion of informality became explicit even before the Salvini Decree, through the adoption of the Circolare Critelli in 2016, a guideline regulating the access to the reception system of migrants, families and vulnerable groups of migrants. The bulletin ordered the exclusion of the reception centres of those, who already found or could have obtained a place in a reception facility and/or who could have benefited from the right to apply for international protection in another state or in any other place in Italy (ASGI, Antenne Migranti, and Fondazione Alexander Langer Stiftung 2017, 15; MSF 2018b, 18).

Informality in northern Italy is further enhanced by the selective re-appearance of internal borders as exemplified by the Ventimiglia case study of Aris (2018). The formation and dissemination of informal settlements, especially in Ventimiglia and Brennero, are direct results of the closure and by this, the re-appearance of intra-European borders. Less people crossing result in more people in limbo and in informality. This claim is supported by Kasparek $(2016,3)$, who argues that through the CEAS, Dublin and Schengen, the border regime was expanded towards the interior of the EU. Borri $(2016,61)$ poses that the European asylum system, and especially returns under Dublin, produce protracted socio-economic and juridical precariousness, which, as this article shows, take place in the form of informality.

\subsection{Classifying and quantifying migrants in informality in Italy}

The population in informality is difficult to quantify, MSF (2018b, 1) speak of 10,000 migrants living out of the reception system in Italy. After having directed the first quantitative survey about informality, Mendola and Busetta (2018) calculate around 7,500. These figures are already some years old and it is very unlikely, that the total amount of refugees and migrants in informality has decreased since then, especially if considering the amount of covert arrivals (see supra) in addition to the political and legal developments, foremost the Decreto Salvini.

There are different groups of migrants in informality in Italy: asylum seekers who are waiting to have their applications processed and to 
enter the (second-grade) reception facilities, transit migrants who aim to cross the border and proceed to another EU country, and migrants or refugees who are living in Italy for several years already, but outside the boundaries of reception (Busetta et al. 2019, 2).

The members of the first two groups are often newly arrived or recently returned migrants, as they drop-out of the reception system after a couple of weeks. Besides that, also asylum seekers whose applications are processed face difficulties to find reception; the second-grade facilities are overstrained and the waiting lists long. People under humanitarian and international protection are similarly affected; the reception system fails to guarantee second-grade reception for them. This displays the particular seriousness of the Italian shelter crisis (Benedikt 2019, 19). Dubliners and those arriving fuori quota are excluded from the reception system as there is so far not a congruent and efficient accommodation strategy for returnees (AIDA 2018, 14; MSF 2016, 12; 2018b, 1).

\section{Methodology and sample}

To elucidate the living realities in camplessness, the emphasize was put on migrants who are or were living in informality. To picture their situations, the reasons for the emerging of informality and the implications of a life outside of the reception system, I conducted single and group interviews with a total of 19 informants. I used Spradley's (1979) ethnographic interview approach with the problem-centred autobiographical narrative for ethnographic research as paragon technique, giving priority to the experiences and assessments of the migrants (Skinner 2012; Svašek and Domecka 2012, 107-27; Lamnek and Krell 2016, 344-49). The interviews were conducted face-toface, in an open, semi-structured and unstandardized way and were complemented with expert interviews and observations.

The multi-sited ethnography took place in May and June 2018 in Brennero, Bolzano, Trento and Ventimiglia. To bring attention to temporary migration sites, I followed the suggestion of an ethnography of infamous vanishing spaces by Tazzioli and Garelli $(2019,407)$.

The interviewees were either of African origin; from Ivory Coast, Morocco, Algeria and Sudan; or Asian; precisely from Afghanistan and Pakistan. The majority of them was from Sudan, the second greatest share of the sample was from Afghanistan. Half of the informants has been present in Europe for more than two years and most of the other half for more than one year. Only three stated that they had just 
arrived in Italy. In Ventimiglia, most migrants were trying to cross the border, while in Trento or Bolzano most of them had the intention to stay. Once in touch with the target group, the snowball sampling method proved its practicality to find research subjects of samples who are not known in numbers, difficult to locate and hard to reach (Cohen and Arieli 2011).

\subsection{Some limitations}

Informal settlements are sites of transition; change is permanently occurring internally through the high degree of mobility; and externally through modifications like forced evictions. My observations can hardly be made in the same sites, of the same persons and under the same circumstances again. These concerns lead to the assumption that the results are not generalizable to other migrant populations or regions. In order to transfer the findings to other groups or areas, inter alia a bigger population, a multiplicity, would have been needed. The multiplicity produced due to spatial proximities, in the underlying case the multiplicity linked to proximity in informality, could not be observed, as the informal settlings are too small and ephemeral to create a true multiplicity, they rather form the contrary; marginalized minorities, a fact that stands for itself. However, one can speak of a multiplicity of all migrants in informality or outside of the reception system in northern Italy. The aim of the research cannot be to deduce statements and apply them to other populations, but to generalize the results to theoretical propositions and to juridical assessments regarding the living realities of arriving and returning migrants in Italy and the shortcomings of the reception and asylum system.

I also must remark that the unequal gender distribution may impair my research; in none of the visited areas I could find women. A similar issue was faced by the researchers of $\operatorname{MSF}(2018 a, 1)$ in Ventimiglia, where they interviewed about 300 individuals, of whose only three percent were female. An alarming fact that should give rise to concerns about what happens to migrating women in Italy.

\section{Results: Reasons for the emerging of informality and living realities outside the boundaries of reception}

During the field research it became evident, that in order to shed light into the living realities, it must be understood, why informality is 
actually on the rise in northern Italy. The reasons for the emerging of informal settlings are directly linked to the living conditions and realities migrants in northern Italy encounter and by implication to the human rights deficiencies.

\subsection{Informality and mobility: an interdependence}

My research confirms the existence of the above-mentioned categories of migrants present in northern Italy (and in informality). These were however complemented by another group of returnees, undertaking what I call an "inverted flight movement". This group turned back to Italy from other EU states, namely Austria, Germany and Sweden, not according to a Dublin procedure, but in a more voluntary way. Several interviewees stated that, after a negative asylum decision and the subsequent issuance of a deportation order back to their states of origin, they opted to go to Italy. The affected informants were either from Pakistan or Afghanistan and virtually unable to comply with the deportation, as they would not be sent back into a safe life, but into a perilous one. To evade the deportation and to escape again the dangerous circumstances that made them once abandon their homelands, they left their countries of refuge towards Italy, undertaking thus what I name an inverted flight movement. It is crucial to mention that the members of this group had been living in the EU for various months or even years as asylum seekers, studying and working legally, and were speaking the language of their former host states well. All of them asked for asylum in Italy and are now waiting to have their applications processed. I encountered this group mainly in the regions of Trentino and Alto Adige. Interestingly, I could identify a regional tendency, as in Ventimiglia the majority of my interview partners returned to Italy as Dubliners or were pushed back, meanwhile along the Brenner Route there was a prevalence of inverted flight movements. Migrants coming to Italy and passing into informality looking for better working opportunities were present in both regions.

What all migrants, those entering Italy in the South and those who came back to Italy from the North, have in common is a high level of mobility. The international mobility, the essence of each flight, does not end after entering the EU or the states of destination. The application of the Dublin Regulation, the difficulties to find work and especially pending deportations and pushbacks keep the migrant population mobile. Not only (re-)entering Italy requires mobility though, even inside the country migrants are constantly compelled to stay itinerant. 
This is due to several reasons like searching work, forced transfers ${ }^{2}$ and evictions (see infra) or the difficulties to find a police station (questura) that accepts asylum applications of migrants fuori quota. Constant mobility means constant alienation and migrants find themselves in a status of non-arrival. Disorientation and helplessness accompany my interviewees. Enduring mobility is enduring readjustment to unknown situations, being mobile entails to sleep mobile and sites of mobility or transit become sites of shelter. Train stations, bridges or parks are typical scenes of camplessness, of non-reception and are the outposts of informality. From there migrants seek housing and entrance into the asylum system.

\subsection{Informality and the overstrained reception system}

In most cases they manage to find a facility of first-grade reception or a homeless shelter, but once inside such an accommodation, the risk of informality is unfortunately not extinct. Homeless shelters are not conceived for migrants; often open only at night and in many cases closed in summer, forcing their inhabitants into informality.

As already mentioned, centres of first-grade reception foresee a limited duration of stay, Hossam for instance was aware of the fact that he would become homeless after expiring the timeframe: 2018).

I am [...] going to sleep [...] in the park (Interview in Trento, June

As many others, Hossam asked for asylum in Italy, and is hence theoretically entitled to a place in a facility for asylum seekers (SPRAR/ SIPROIMI or CAS). The reality however only offers a place in informality:

For us there is a reception accommodation [but] they say waiting waiting waiting; there is no free place (Group interview in Bolzano, June 2018).

Those who do not apply for asylum, knowing that their claims would be futile, and those whose applications had been rejected, have to stay outside and/or wait for a place in one of the few CAS centres.

2 The Italian authorities forcedly transfer migrants out of informal settlements on the French-Italian border region to the hotspots in the South. This was not only reported by my interview partners but also by Tazzioli and Garelli (2018; 2016). 
Apart from these involuntary "drop-outs" of the reception system, there is a more proactive way of leaving the facilities, of "stepping-out", when the individual choices of the migrants lead them into informality. Stepping out can have different motives. Migrants in the North exit the reception system in order to pursue their flight plans and to cross the border. After having left a facility though, migrants are not allowed to reenter. Accordingly, if their attempt to leave Italy fails, they are campless again. Needless to add, that the strategic spots for onward migration, like border posts or train stations and the meeting points with smugglers are never inside reception facilities, making egress unavoidable.

Work can be another factor producing step-outs, as migrants who aim to earn money in the informal labour market need to be mobile in order to react to demands and opportunities.

I would like to highlight the third motive though, concerning the conditions inside the reception centres. My interviews proved that inadequate living conditions and the lack of services are an issue pertaining to the entire reception regime. The centres of first arrival, the CPSA and hotspots are not in a persuasive status, Abushakar for example mourned the lack of water (Interview in Bolzano, June 2018). The CAS structure and the emergency facilities, like homeless shelters, are not satisfactory in this regard either. Due to the chronic congestion, the rooms are overcrowded with up to 20 men in one room, producing hassle instead of tranquillity. The dissemination of contagious diseases is a side-effect of the density and the lack of hygiene:

The rooms are very very small, they are made for only four to five persons, but 20, 25 or 18 people sleep there. Everybody is sick [...] but in the room all sleep together and so even the healthy persons get sick. The worst thing is the sickness! (Group interview in Bolzano, June 2018).

This phenomenon also applies to Ventimiglia, where Said and Abdel prefer to stay outside and Shaqir states:

Beds are small, the bathrooms are dirty and there is not enough food (Interviews in Ventimiglia, June 2018).

The reasons for the emerging of informality in northern Italy are thus connected to the defective and overburdened reception system.

Informality is closely linked to mobility; the European migration regime indirectly requires migrants to stay mobile in order to pursue their destinations and aims. Mobility however goes hand in hand with 
informality. The Italian asylum and reception system is not capable of dealing with this highly mobile and numerous migrant population in the North and pushes into an accommodation void. Until a secondgrade reception facility is found, migrants drop- and step-out of the first-grade or interim reception centres, trying to attain a more dignified and self-determined living.

\subsection{Living realities and issues in informality}

Despite the fact that the living conditions in the reception centres are often too bad to bear, the circumstances in informal settlings or "under the bridge are not good either" (Interview with Said in Ventimiglia, June 2018).

I uncovered two sets of issues: one connected to the general living conditions, regarding shelter, sanitation and health, and the other linked to the reactions of state authorities towards informality; namely arbitrariness, ignorance, forced evictions and transfers. The absence of protection and adequate shelter like the lack of services, (i.e. the camplessness), are the root causes for both sets of issues. Migrants living outside are exposed to wind, weather and natural hazards. They lack sanitation and are widely excluded from the health care system. Hence, diseases are an omnipresent problem:

under the bridge we get sick as well anyway, there, everything is dirty. When it rains, the river comes up, everyone [is] afraid, when we sleep, and the water comes up. When it rains, everything gets wet, clothing, shoes... (Group interview in Bolzano, June 2018).

Camplessness involves the absence of security, and criminality becomes a side-effect of the seclusion in informality, where violent interactions among migrants are taking place. The lack of support criminalizes migrants and stealing may become a last resort. The authorities do not interfere in such confrontations, my informants complained. Subsequently, mistrust towards state authorities is growing and aggravated, as informal encampments, even the simplest roosts, are regularly evicted. Forced evictions in Ventimiglia went hand in hand with forced transfers of the dwellers:

I noted a pervasive fear as the migrants living under the bridge disappeared after the eviction -no one could really tell where they had gone or been brought to (Field notes in Ventimiglia, June 2018). 
As Abdel reveals, the evictions and transfers increase mistrust and produce growing marginalization. The migrants hide and move to settlings in more remote areas (Interview in Ventimiglia, June 2018).

Forced evictions and transfers thus reproduce and foment what they aim to bury, the emerging of informality and the continuous mobility and marginalization of migrants.

Finally, migrants never find peace, a safe space, a place to rest and to recover. They are in a vicious circle of informality and marginalization. As a consequence, they are also unreachable in the rare case that they would be listed for a place in a second-grade reception facility.

\section{Camplessness and human rights}

As shown, the living realities of migrants in northern Italy are appalling; the conditions inside and outside the reception system give rise to concerns regarding the Italian and European asylum system. The circumstances unveiled by my findings can hardly be accepted from a human rights perspective. In the following subsections, I will try to uncover some of the gravest shortcomings, offering a person-centred view to depict how human rights fail to protect migrants even at the heart of Europe.

\section{1. (Im-)mobility as an effect of EU law}

Even though MSF $(2018 b, 18)$ already observed what I have called "inverted flight movements", I would like to highlight the novelty and relevance of these altered mobility patterns and reiterate what they depict: the (negative) long-term effects of incongruent migration regimes within the EU firstly, of European law enforcement secondly, of diverging status determination practices thirdly, and the denial of protection to a vast proportion of fleeing individuals fourthly. In short, these new forms of intra-European onward migration are a result of responsibility shifting instead of sharing. The denial of responsibility performed by Italy first, then by the EU and then by Italy again, bolsters the hypermobility of migrants and the emergence of informality across Europe (Fontanari 2018, 27).

Brekke and Brochmann $(2015,160)$ explicitly blame the Dublin Regulation for keeping migrants mobile, which involves enduring 
informality as I demonstrated. Borri and Fontanari $(2015,203,209)$ reached the same conclusions during their study of migratory movements between Italy and Germany, stating that mobility is the misappropriate normality for transit migrants and that this is directly linked to precariousness. In my research, this higher risk of precariousness is also ascertained to re-arriving migrants.

When mobility as a reason for informality is scrutinized from a human rights perspective, one cannot be sure whether it was a foreseen effect of the EU regulations. However, as it appears to be the case, these effects must be seen even more critically when taking into account the right to liberty, freedom of movement and to seek asylum and protection, as enshrined in the most fundamental human rights instruments: the UDHR, the ICCPR and the ECHR. Among the latter, especially Art. 2 of the Protocol No. 4 to the Convention (ECHR), underpinning the freedom of movement and the freedom to choose residence, is worth highlighting. These guarantees may be restricted as prescribed under Para. 3 and Para. 4 of the Article; however, the reasons for the restrain of liberty and of forced mobility as examined here, fall not under the provisions of possible restrictions. Relocation and returning under Dublin pose disenfranchisements of the freedom of choice and the right to freedom of movement.

\subsection{On the wrong side of the law: the (non-)reception system}

Informality and the Italian asylum and reception system are not to be seen as two separate issues. They are closely linked to each other, migrants shift between "illegal" and legal, awaiting reception, and dropping-out into informality is finally the consequence of this condition. Informality and camplessness are produced and reproduced by the sistema di accoglienza, and yet an inherent part of it, taken into account by the Italian authorities, as the Salvini Decree proves.

Bearing in mind not only the exclusionary administrative aspects, but also the poor living conditions inside the facilities and the effects of mobility produced by law enforcement, the step-outs are to be seen as the other part of the consequences. Individual choices to exit the reception system and to re-enter Italy in order to bypass deportations, as unveiled in this article, show another aspect of the autonomy of migration narrative. In this case, the circumventing of deportations and the stepping-out of the reception regime are proofs of migrants' capacity to pursue their goals and to act independently, even in a system of illegalization and confinement. 
The circumstances producing the exclusion of the reception system and the living conditions both inside and outside the latter violate various provisions of international law. Firstly and foremost, Art.3 of the ECHR, but as well and more precisely the Reception Conditions Directive and the ESC (European Social Charter). The Directive 2013/33/ EU of the European Parliament and of the Council of the EU lays down the standards for the reception of applicants for international protection. The step-outs prove that the Italian system falls short to meet especially the provisions of Art. 7, 17, 18, 19 and 21 .

The ESC safeguards the right to housing, and hence of reception and protection of homelessness, in three provisions, namely Art. 16, 19.4 and 31. According to the appendix of the ESC, this protection includes only migrants legally present and resident in the state; however, the ESCR (European Committee on Social Rights) has ruled that people who fall not under the definition of the appendix still have a claim and cannot be excluded from rights protecting their life and dignity. ${ }^{3}$

\subsection{Outside the boundaries of reception and outside the boundaries of law}

The living conditions outside the reception system are worse than expected; migrants in informality are living as homeless in humanitarian plight. Bearing in mind the legal provisions regulating the right to housing and the reception conditions, it is obvious that homelessness and the precarious livelihoods migrants of all different legal statuses are encountering outside of reception are not in line with international human rights law.

The perilous living conditions are further aggravated by methods of repression like forced evictions and transfers of migrants. These practices are not only disenfranchising and discriminating, they also contradict the full spectrum of human, civil, cultural, economic, political and social rights enshrined in international instruments and international legally binding documents (UN-HABITAT 2014, 6). Inter alia, I would like to highlight Art. 6.1, 7 and 9.1 of the ICCPR and Art. 11 of the ICESCR. On the European level, ECHR Art. 8 and Art. 1 of its Protocol 1 protect from forced evictions and the destruction of property. Besides, the obligation to provide and promote housing of

3 COHRE v. Italy, Complaint No. 48/2009, merits, 25 June 2010, paragraph 33. 
Art. 31 of the ESC (see supra) also amounts to protection from unlawful eviction. ${ }^{4}$

\subsection{Future perspective and role of the findings for the research field}

This paper enhances existing knowledge on the situation of refugees and migrants in the EU and, in particular, of arriving and rearriving migrants in northern Italy. It bridges the knowledge gap about migrant informality in EU/high-income countries, offering an insight view into the downsides of the Italian reception system. By showing that camplessness is produced by the enforcement of restrictive migration regulations in Italy and elsewhere in Europe, this article aims to open a critical discussion towards the uneven reception of refugees and migrants in Europe. It further delivers a future perspective about the long-term effects of the lack of unity of the EU Member States on how to respond to immigration. Differing reception conditions foster mobility and secondary migration in Europe, challenging at the same time the European migration policies of the CEAS and human rights. Here, the application of the Dublin Regulation and of deportations and pushbacks must be seen critically, as they indirectly lead into precariousness and increase the "load" Italy has to carry.

My findings about migrant living and moving in northern Italy can be used as a basis for future investigations and for more in-depth research. This article also aims to contribute to legal assessments of the situation of migrants and refugees or beneficiaries of international protection in Italy. As for the results and the brief discussion of only some of the human rights instruments, I would like to sensitise legal practitioners and scholars to informality and query whether returning/ deporting migrants to Italy can be a feasible option, if camplessness and marginalisation await.

In light of the previous pages and the vast human rights breaches that are taking place, although out of sight and under the guise of other legal instruments, but still in the middle of Europe, it seems that law breaking is the new way towards law making in Italy. Disrespecting migrants' rights found its equivaling justification in the

${ }^{4}$ Case law in this regard so far includes mainly forced evictions of Roma people, for instance in: ERRC v. Greece, Complaint No. 15/2003, merits, 8 December 2004, paragraph 24.

However, the action of forcibly evicting people is to be seen as unlawful per se, notwithstanding the migratory background of the evicted subjects. 
defective reception system, the Circolare Critelli and the Salvini Decree, whose constitutionality is not even guaranteed. Regarding other European states, things do not give reasons for optimism either, when deportations into regions of combat, misery or plight are the erroneous normality and when significant numbers of refugees perish on their way towards Europe.

\section{Conclusion}

Getting back to the initial question about the future of refuge, it must be admitted that in Italy informal settlements appear to be this future; More than 10,000 migrants live outside a reception system, which is not only overloaded and desolate, but also profoundly exclusive. The answer to informality is hostility though, with evictions being a common practice, forcing vulnerable people into even more perilous environments. Looking at northern Italy, it becomes clear that informal settlements are non-camps, which lack any equivalent in common definitions, and can thus not be included in camp scholarship. These informal settlings are forms of spatial segregation, non-permanent arrangements of insufficient shelter, where the living realities are worse than in camps and, therefore, beyond of what Agamben (1998) called "bare-life". Campless migrants in northern Italy are subsisting "barer-lives", away from society and pushed to exclusion rather than empowered to integration. They are in a status of non-arrival, passing from legal to "illegal", as errant subjects in a vicious circle of informality.

The access to and the enjoyment of the rights that protect migrants are only exiting in theory and it seems that even their written existence is vanishing, taking into account the recent juridical developments in Italy; in particular, the adoption and un-appealed persistence of the Salvini Decree. Migrants' rights are under attack directly by such laws and indirectly by the European migration regime; namely deportations, pushbacks, and the rigorous application of the Dublin Regulation. The status quo of reception in northern Italy is not in accordance with the human rights guaranteed by the foundations of the EU and the UN. The discordant European answer to migration and its disenfranchising laws turn Italy into an open-air prison. The ingress is the fingerprint upon arrival and migrants will always have to return to this prison due to the application of the Dublin Regulation and the enforcement of deportations. Informal settlements are an opaque strategy to avoid this imprisonment and should be apprehended as a humanitarian 
emergency, but also as a form of resistance and autonomy, challenging the system of illegalization.

Returning migrants to Italy must be seen critically, not just for families or unaccompanied minors; homelessness cannot be the perspective for people seeking protection in Europe. There is need for a more progressive jurisprudence taking research into account and putting barriers onto Dublin returns that neglect human rights. Italy is not receiving migrants and refugees as prescribed by law and by implication, the EU is not either. Returns to Italy are likely to contradict the principle of Non-Refoulement.

\section{References}

Agamben, Giorgio. 1998. Homo Sacer: Sovereign Power and Bare Life. Homo Sacer 1. Stanford: Stanford University Press.

Agier, Michel. 2002. "Between war and city: Towards an urban anthropology of refugee camps». Ethnography 3 (3): 317-41.

AIDA. 2018. Country Report: Italy. Brussels: ECRE.

Aris, Juan P. 2018. "La paradoja del taxista: Ventimiglia como frontera selectiva». Mondi Migranti, no. 2 (September): 99-114.

ASGI, Antenne Migranti, and Fondazione Alexander Langer Stiftung. 2017. Lungo la Rotta del Brennero. Rapporto di monitoraggio della situazione dei migranti a Bolzano e al Brennero. Accessed November 12, 2019. https:// www.asgi.it/wp-content/uploads/2017/09/2017_Report_Monitoraggio_ Bolzano_Brennero_25_09.pdf

Belloni, Milena. 2016. "Learning how to squat: Cooperation and conflict between refugees and natives in Rome». Journal of Refugee Studies 29 (4): 506-27.

Benedikt, Sebastian. 2019. "Along the Brenner route. The emerging of informal refugee camps in Europe. Bolzano: A case study research». Lungo La Rotta Del Brennero Series. Bolzano: Antenne Migranti, Fondazione Alexander Langer Stiftung.

Borri, Giulia. 2016. "Mobilità intra-Europea: Il caso dei movimenti di ritorno a Torino di migranti titolari di protezione umanitaria». Mondi Migranti, no. 1: 61-82.

Borri, Giulia, and Elena Fontanari. 2015. «Lampedusa in Berlin: (Im)Mobilität Innerhalb Des Europäischen Grenzregimes». Peripherie 35 (138-139): 193211.

Brekke, Jan-Paul, and Grete Brochmann. 2015. «Stuck in transit: Secondary migration of asylum seekers in Europe, national differences, and the Dublin regulation». Journal of Refugee Studies 28 (2): 145-62.

Brighenti, Andrea M. 2016. Urban Interstices: The Aesthetics and the Politics of the in-Between. New York: Routledge. 
Busetta, Annalisa, Daria Mendola, Ben Wilson, and Valeria Cetorelli. 2019. «Measuring vulnerability of asylum seekers and refugees in Italy». Journal of Ethnic and Migration Studies, (1-20). DOI: 10.1080/1369183X.2019.1610368

Camera Deputati. 2018. Comitato parlamentare di controllo sull'attuazione dell'accordo di Schengen, di vigilanza sull'attività di Europol, di controllo e vigilanza in materia di immigrazione. Audizione 1. Seduta Mercoledì 5 diciembre 2018. Atti Parlamentari. Rome: Senato Republica. Accessed November 12, 2019. http://documenti.camera.it/leg18/resoconti/commissioni/ stenografici/pdf/30/audiz2/audizione/2018/12/05/leg.18.stencomm. data20181205.U1.com30.audiz2.audizione.0001.pdf

Campesi, Giuseppe, and Giulia Fabini. 2020. «Immigration detention as social defence: Policing "dangerous mobility" in Italy». Border Criminologies (blog). Accessed April 2, 2020. https://www.law.ox.ac.uk/research-subject-groups/ centre-criminology/centreborder-criminologies/blog/2020/04/immigration.

Caritas and Ministero dell'Interno. 2012. Mediazioni Metropolitane: Studio e Sperimentazione Di Un Modello Di Dialogo e Intervento a Favore Dei Richiedenti e Titolari Di Protezione Internazionale in Situazione Di Marginalità. Rome: Ministero dell'Interno.

Cohen, Nissim, and Tamar Arieli. 2011. «Field research in conflict environments: methodological challenges and snowball sampling». Journal of Peace Research 48 (4): 423-35.

Corrado, Alessandra. 2011. "Clandestini in the orange towns: Migrations and racisms in Calabria's agriculture». Race/Ethnicity: Multidisciplinary Global Contexts 4 (2): 191-201.

Cosgrave, John, Karen Hargrave, Marta Foresti, Isabella Massa, Justin Beresford, Helen Dempster, and Joanna Rea. 2016. Europe's Refugees and Migrants. Hidden Flows, Tightened Borders and Spiralling Costs. London: Overseas Development Institute.

Cristaldini, Flavia. 2015. «I nuovi schiavi. Gli immigrati del Gran Ghetto di San Severo». Rivista geografica italiana 122 (1): 119-42.

De Genova, Nicholas. 2012. "Bare life, labor-power, mobility, and global space: Toward a Marxian anthropology?» CR: The New Centennial Review 12 (3): 129-51.

De Genova, Nicholas, Glenda Garelli, and Martina Tazzioli. 2018. «Autonomy of Asylum?» South Atlantic Quarterly 117 (2): 239-65.

Dembour, Marie-Bénédicte, and Marie Martin. 2011. «The French Calaisis. Transit zone or dead-end?» In Are Human Rights for Migrants? Critical Reflections on the Status of Irregular Migrants in Europe and the United States, edited by Marie-Bénédicte Dembour and Tobias Kelly, 124-45. New York: Routledge.

Fontanari, Elena. 2016. "Subjectivities en transit. Fragmented everyday lives of temporary refugees (im)mobile between European borders». PhD diss., Milano: Università degli Studi di Milano.

Fontanari, Elena. 2017. «lt's my life. The temporalities of refugees and asylum seekers within the European border regime». Etnografia e Ricerca Qualitativa, no. 1: 25-55. 
Fontanari, Elena. 2018. "Looking for neverland The experience of the group Lampedusa in Berlin and the refugee protest of Oranienplatz». In Witnessing the Transition: Moments in the Long Summer of Migration, edited by Gökçe Yurdakul, Regina Römhild, Anja Schwanhäußer, and Birgit zur Nieden, 15-34. Berlin: Berlin Institute for Empirical Integration and Migration Research.

Fontanari, Elena, and Maurizio Ambrosini. 2018. «Into the interstices: Everyday practices of refugees and their supporters in Europe's migration "crisis" ». Sociology 52 (3): 587-603.

Giannetto, Leila; Ponzo, Irene; Roman, Emanuela. 2019. «National report on the governance of the asylum reception system in Italy». In Ceaseval research on the common European asylum system (21). Accessed April 23, 2020. http://ceaseval.eu/publications/WP3_Italy.pdf

Giuffrida, Angela. 2018. "Between Italy's cliffs and sea, migrants bid to outwit police». The Guardian, Accessed June 17, 2018. https://www.theguardian. com/world/2018/jun/17/italy-ventimiglia-migrants-stuck-at-border-crisissuffering.

Habib, Rima R., Diana Mikati, Safa Hojeij, Khalil El Asmar, Monique Chaaya, and Rami Zurayk. 2016. "Associations between poor living conditions and multi-morbidity among Syrian migrant agricultural workers in Lebanon». The European Journal of Public Health 26 (6): 1039-44.

Hess, Sabine. 2012. "De-naturalising transit migration. Theory and methods of an ethnographic regime analysis». Population, Space and Place 18 (4): 428-40.

Hess, Sabine, Bernd Kasparek, Stefanie Kron, Mathias Rodatz, Maria Schwertl, and Simon Sontowski, eds. 2017. Der lange sommer der migration. 2. korrigierte Auflage. Grenzregime 3. Berlin Hamburg: Assoziation A.

Kasparek, Bernd. 2016. "Complementing Schengen: The Dublin system and the European border and migration regime». In Migration Policy and Practice, edited by Harald Bauder and Christian Matheis, 59-78. New York: Palgrave MacMillan.

Khrebtan-Hörhager, Julia. 2019. «Intersectional othering and new border cultures: Lessons from Italy». Women's Studies in Communication 42 (2): 125-29.

Korac, Maja. 2003. "The lack of integration policy and experiences of settlement: A case study of refugees in Rome». Journal of Refugee Studies 16 (4): 398-421.

Kreichauf, René. 2018. "From forced migration to forced arrival: The campization of refugee accommodation in European cities». Comparative Migration Studies 6 (1). doi: 10.1186/s40878-017-0069-8

Lamnek, Siegfried, and Claudia Krell. 2016. Qualitative Sozialforschung: mit Online-Material. 6, überarbeitete Auflage. Weinheim Basel: Beltz.

Mendola, Daria, and Annalisa Busetta. 2018. «Health and Living Conditions of Refugees and Asylum-Seekers: A Survey of Informal Settlements in Italy». Refugee Survey Quarterly 37 (4): 477-505.

Menghi, Marta. 2018. «Intorno alla frontiera: politiche di contenimento e pratiche di mobilità sul confine di Ventimiglia». Mondi Migranti, no. 2: 39-60. 
Minca, Claudio. 2015. «Counter-camps and other spatialities». Political Geography 49: 90-92.

MSF. 2016. Out of Sight - Asylum Seekers and Refugees in Italy: Informal Settlements and Social Marginalization. Rome: Doctors without borders.

MSF. 2018a. Harmful Borders. An Analysis of the Daily Struggle of Migrants as They Attempt to Leave Ventimiglia for Northern Europe. Rome: Doctors without borders.

MSF. 2018b. Informal Settlements: Social Marginality, Obstacles to Access to Healthcare and Basic Needs for Migrants, Asylum Seekers and Refugees. Rome: Doctors without borders.

Picozza, Fiorenza. 2017. "Dublin on the move. Transit and mobility across Europe's geographies of asylum». Movements 3 (1): 71-88.

Pinelli, Barbara. 2015. "After the landing: Moral control and rurveillance in Italy's asylum seeker camps». Anthropology Today 31 (2): 12-14.

Piro, Valeria, and Giuliana Sanò. 2017. «Abitare (Ne)i Luoghi Di Lavoro: II Caso Dei Braccianti Rumeni Nelle Serre Della Provincia Di Ragusa». Sociologia del Lavoro, no. 146: 40-55.

Puggioni, Raffaela. 2005. «Refugees, institutional invisibility, and self-help strategies: Evaluating Kurdish experience in Rome». Journal of Refugee Studies 18 (3): 319-39.

Queirolo, Luca. 2017. «Nuit debout. Transiti, connessioni e contestazioni negli accampamenti urbani dei rifugiati a Parigi». Mondi Migranti, no. 2: 207-27.

Sanò, Giuliana. 2017. «Inside and outside the reception system. The case of unaccompanied minors in Eastern Sicily». Etnografia e ricerca qualitativa, no. 1: 121-142.

Sanyal, Romola. 2017. "A no-camp policy: Interrogating informal settlements in Lebanon». Geoforum 84: 117-25.

Sigona, Nando. 2015. "Campzenship: Reimagining the camp as a social and political space». Citizenship Studies 19 (1): 1-15.

Skinner, Jonathan, ed. 2012. The Interview: An Ethnographic Approach. London: Berg.

Sperber, Amanda. 2018. "Mediators help migrants access health services in Italy». The Lancet 391 (10129): 1468-69.

Spradley, James P. 1979. The Ethnographic Interview. New York: Holt, Rinehart and Winston.

Sukarieh, Mayssoun, and Stuart Tannock. 2013. "On the problem of overresearched communities: The case of the Shatila Palestinian refugee camp in Lebanon». Sociology 47 (3): 494-508.

Svašek, Maruška, and Markieta Domecka. 2012. "The autobiographical narrative interview: A potential arena of emotional remembering, performance and reflection». In The Interview: An Ethnographic Approach, edited by Jonathan Skinner, 107-27. London: Berg.

Tazzioli, Martina, and Glenda Garelli. 2016. «Beyond detention: Spatial strategies of dispersal and channels of forced transfer. Governing mobility through European hotspot centres». Society and Space. DOI: 10.1177/0263775818759335 
Tazzioli, Martina, and Glenda Garelli. 2018. «Containment beyond detention: The hotspot system and disrupted migration movements across Europe». Environment and Planning D: Society and Space.

Tazzioli, Martina, and Glenda Garelli. 2019. "Counter-mapping, refugees, and asylum borders». In Handbook on Critical Geographies of Migration, edited by Katharyne Mitchell, Reece Jones, and Jennifer L. Fluri, 397-409. Cheltenham: Edward Elgar.

Tondo, Lorenzo, and Angela Giuffrida. 2018. «Vulnerable migrants made homeless after Italy passes "Salvini Decree" ». The Guardian. Accessed July 12, 2018. https://www.theguardian.com/world/2018/dec/07/vulnerablemigrants-made-homeless-after-italy-passes-salvini-decree.

Turner, Simon. 2016. "What is a refugee camp? Explorations of the limits and effects of the camp». Journal of Refugee Studies 29 (2): 139-48.

UNECE. 2009. Self-Made Cities: In Search of Sustainable Solutions for Informal Settlements in the United Nations Economic Commission for Europe Region. Edited by United Nations, S. Tsenkova, Chryssy Potsiou, and Anna Badyina. Switzerland: UNECE Information Service.

UN-HABITAT. 2014. Forced Evictions Fact Sheet No. 25/Rev.1. Fact Sheet 25. Geneva: UN.

UNHCR. 2018. Key Figures on Arrivals and Asylum Applications in the EU-2017: Key Data for Europe 2017. Geneva: UNHCR.

UNHCR. 2019. Mediterranean Situation: Italy. Operational Portal Refugee Situations. Accessed November 11, 2019. https://data2.unhcr.org/en/ situations/mediterranean/location/5205.

UNHCR Lebanon. 2016. Informal Settlements of Syrian Refugees in Lebanon. Dataset. 2016. Accessed November 13, 2019. https://data.humdata.org/ dataset/syrian-refugeees-informal-settlements-in-lebanon. 


\section{Copyright}

Deusto Journal of Human Rights / Revista Deusto de Derechos Humanos is an Open Access journal; which means that it is free for full and immediate access, reading, search, download, distribution, and reuse in any medium only for non-commercial purposes and in accordance with any applicable copyright legislation, without prior permission from the copyright holder (University of Deusto) or the author; provided the original work and publication source are properly cited (Issue number, year, pages and DOI if applicable) and any changes to the original are clearly indicated. Any other use of its content in any medium or format, now known or developed in the future, requires prior written permission of the copyright holder.

\section{Derechos de autoría}

Deusto Journal of Human Rights / Revista Deusto de Derechos Humanos es una revista de Acceso Abierto; lo que significa que es de libre acceso en su integridad inmediatamente después de la publicación de cada número. Se permite su lectura, la búsqueda, descarga, distribución y reutilización en cualquier tipo de soporte sólo para fines no comerciales y según lo previsto por la ley; sin la previa autorización de la Editorial (Universidad de Deusto) o la persona autora, siempre que la obra original sea debidamente citada (número, año, páginas y DOI si procede) y cualquier cambio en el original esté claramente indicado. Cualquier otro uso de su contenido en cualquier medio o formato, ahora conocido o desarrollado en el futuro, requiere el permiso previo por escrito de la persona titular de los derechos de autoría. 